scien do Zagreb International Review of Economics \& Business, Vol. 22, Special Conference Issue, pp. 39-53, 2019 (C) 2019 Faculty of Economics and Business, University of Zagreb and De Gruyter Open All rights reserved. Printed in Croatia ISSN 1331-5609; UDC: $33+65$

DOI: 10.2478 /zireb-2019-0026 CONFERENCE PAPER

\title{
Consumer Satisfaction on Online Services in Kosovo
}

\author{
Besim Beqaj* \\ Arta Krasniqi** \\ Valon Beqaj ${ }^{* * *}$
}

\begin{abstract}
This paper aims to analyse and examine consumer behaviour based on different variables (age, gender, level of education, income, customer care, delivery time), and the impact of those variables on consumer satisfaction on domestic and foreign online services in Kosovo. The data represented in the paper have been collected on 2017 and 2019. The majority of demographic variables (except gender and income) as independent variables have shown to be significant in explaining consumer satisfaction from online services. On the contrary, the level of customers' gender and income have shown to be statistically insignificant ( $p=0.143$ and $p=0.264$ respectively; where $\alpha=5 \%$ ). In addition, income has shifted from being insignificant in 2017 to significant in 2019. It can be inferred that the strongest correlation has shifted towards the price level of the $4 P$ 's of Marketing with total customer satisfaction from online services $(r=.996)$, followed by customer care $(r=.990)$.
\end{abstract}

Keywords: the consumer; e-Commerce; customer satisfaction; marketing mix; costumer care

JEL Classification: M11, M14, M30, L81

\section{Introduction}

Technology has been a significant driver of production thorough history. Nevertheless, the potential for exploiting the benefits of technology laid its foundation with the beginning of the Industrial Revolution (Rifkin, 2013); followed by an exponential growth in the last decades. These advancements enabled a new dimension in terms of interaction, communication and even the initiation of financial transactions. (Shafiee \& Bazargan, 2018) Virtual platforms have been created which initially have served

\footnotetext{
${ }^{*}$ Besim Beqaj is at University of Prishtina, Prishtina, Kosovo.

** Arta Krasniqi is at University of Prishtina, Prishtina, Kosovo.

**** Valon Beqaj is at Kent State University.
} 
as communication means, followed by the ability to share data and interact with one another across the globe. Furthermore, technological advancement has introduced a completely new way of exchanging products and services (Shafiee \& Bazargan, 2018). Nowadays, individuals are able to make use of different online platforms to perform various types of purchases in terms of products as well as services. This type of commerce is nowadays known as e-Commerce (electronic commerce) (Grandon $\&$ Pearson, 2004).

Accordingly, businesses must adapt to these changes as a continuous attempt to establish sustainable competitive advantage. As Barney states "firms obtain sustainable competitive advantage by implementing strategies that exploit their internal strength, through responding to environmental opportunities, while neutralizing external threats and avoiding internal weaknesses" (Barney, 1991), so it is in the interest of firms to have a better understanding of the environment in which they operate i.e. Porter's five forces that impact an industry (Porter, 1980). One key component of doing business is having a better understanding of one's customer base and their needs. Therefore, consumer satisfaction has continuously been a significant topic of competitive - advantage seeking firms in the sense that loyalty (switching cost) can be a product of consumer satisfaction (Wilson, et al., 2016). In order to analyse satisfaction, it is significant to understand what it is. According to Kotler, consumer satisfaction is the positive feeling that a consumer has when his/her needs are met in correlation to his/her expectations (Kotler, \& Keller, 2012).

Therefore, consumer satisfaction has a direct implication on products, their prices, promotion, and distribution (place) (Kotler, \& Keller, 2012). This study values society, culture and behavior as influential factors thus, a questionnaire has been conducted in the effort to explain consumer satisfaction on online services in Kosovo.

To the best of our knowledge, this is the first attempt to investigate satisfaction on online services in Kosovo, and therefore we believe that it will fill in a considerable gap in the existing literature regarding both consumer satisfaction and online services.

\section{Questionnaire design}

The questionnaire has been designed to analyze satisfaction based on age, gender, location, education, product variation, price, distribution, delivery time as well as customer care services. The questionnaires have been conducted twice (2017 and 2019) where changes have been observed. The questionnaire has been distributed to 1,100 individuals in 2019 and 1,224 in 2017 across five major cities in Kosovo (Prishtina, Peja, Gjakova, Prizeren, and Mitrovica).

Of those, 850 individuals responded to the questionnaire, amounting to a $77 \%$ response rate in 2019 and 69\% response rate in 2017. 
First five questions aim to capture main demographic characteristics of respondents such as (age, gender, education, residence, and income), the rest of the questions are constructed according to Likert scale approach which helps to best evaluate the degree of satisfaction form online services in Kosovo. The questionnaire deals with issues regarding 4p's of marketing (product variation, price, promotion, distribution) as well as further investigation of delivery time and customer care.

As per demographics (shown in the graph below), 56\% of the respondents in 2019 where female and 44\% male. On the other hand, almost half of the respondents $(49 \%)$ fall between the age of 25 and 34 years, which is consistent with our assumptions that millennials represent most online platform users. Income level of our respondents seem to be evenly distributed among different rates. The same cannot be said in terms of education level, where the majority of the respondents $(51 \%)$ had a university degree.

Figure 1: Demographics 2019
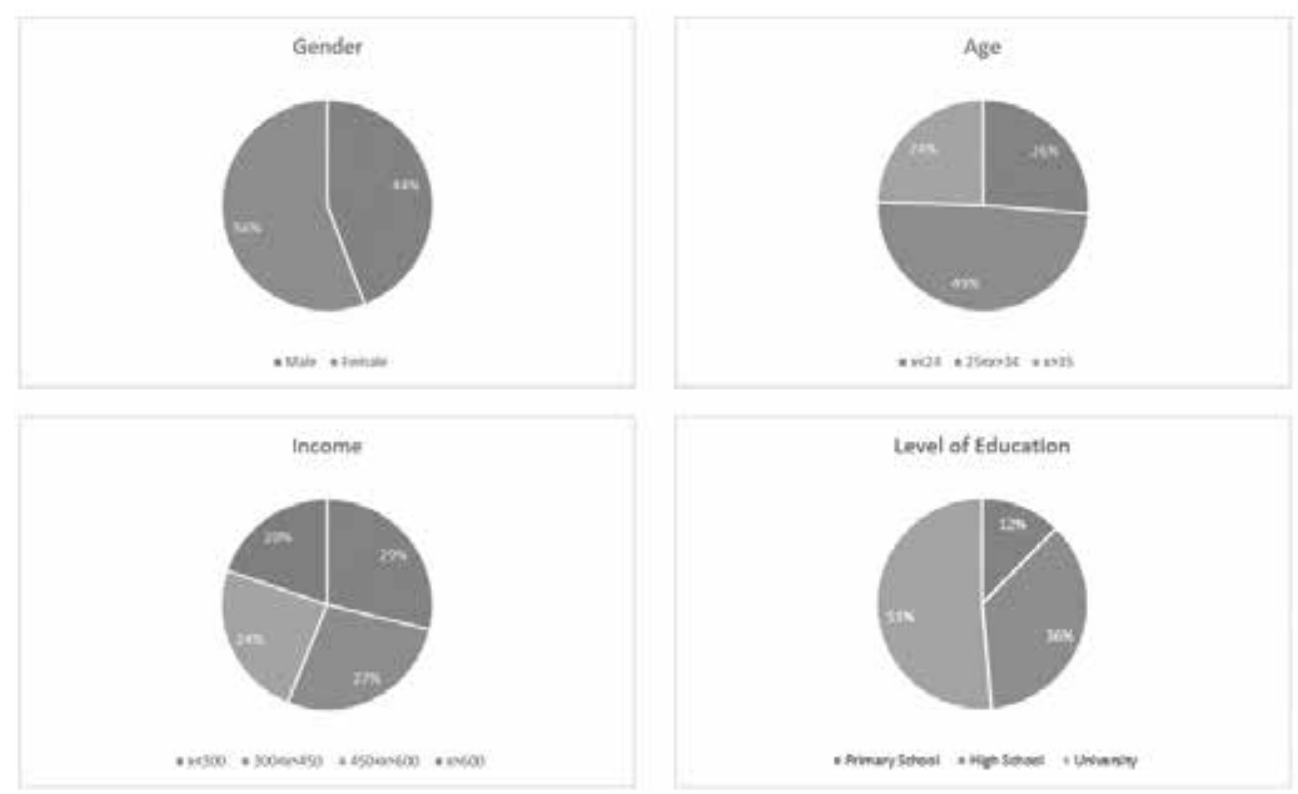

A slightly different response rate was observed in 2017 as can be seen in the graph below. 
Figure 2: Demographics 2017
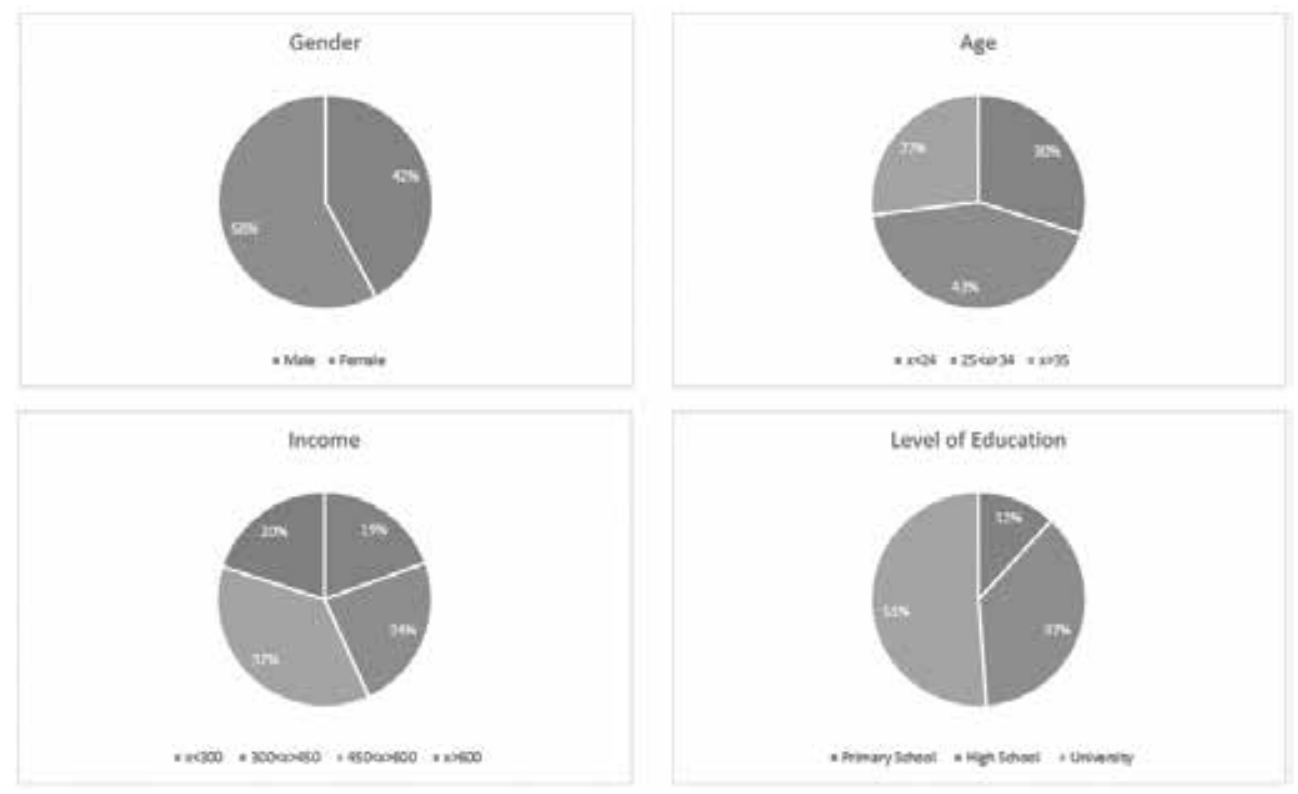

Finally, the collected data have been analysed with the effort to better understand what drives consumer satisfaction on online services in Kosovo, and how does the significance of variables change over time.

\section{Methodology}

In order to analyse the collected data, a number of statistical methods have been used: descriptive method, which has served to describe the results obtained through questionnaire, Cronbach's Alfa, which is used to test the reliability of variables, bivariate correlation method, which is an analysis that measures the strength of relationship between two variables, multivariable regression method for testing hypotheses and crosstabs and test contingency or HI-squared test, which helped us to test other hypotheses, as well as ANOVA which indicates analysis of variance. All the test and methods where conducted for the data gathered in 2017 as well as 2019.

The data have been processed by using Microsoft Office Excel and SPSS (Statistical Package for the Social Sciences). 


\section{Contingency test of $X 2$}

Contingency test is used to assess whether differences between the average values of two samples are statistically significant (Pearson, 1904). In our case, it is used to test the following hypothesis:

H1 - There is a significant relationship between age of customers and the level of satisfaction with online services.

$\mathrm{H} 2$ - There is a significant relationship between gender of customers and the level of satisfaction with online services.

$\mathrm{H} 3$ - There is a significant relationship between the residence of customers and the level of satisfaction for online services.

$\mathrm{H} 4$ - There is a significant relationship between the level of education of customers and the level of satisfaction with online services.

H5 - There is a significant relationship between the income of customers and the level of satisfaction with online services.

Table 1: Chi-Square Tests Contingency Test 2017

\begin{tabular}{|c|c|c|c|}
\hline 2017: Age and customer satisfaction & Value & Df & $\begin{array}{c}\text { Asymptotic Significance } \\
\text { (2-sided) }\end{array}$ \\
\hline Pearson Chi-Square & $13.627^{\mathrm{a}}$ & 6 & .034 \\
\hline Likelihood Ratio & 15.964 & 6 & .014 \\
\hline $\mathrm{N}$ of Valid Cases & 850 & & \\
\hline $\begin{array}{l}\text { 2017: Gender and customer } \\
\text { satisfaction }\end{array}$ & Value & Df & $\begin{array}{c}\text { Asymptotic Significance } \\
\text { (2-sided) }\end{array}$ \\
\hline Pearson Chi-Square & $3.976^{\mathrm{a}}$ & 3 & .264 \\
\hline Likelihood Ratio & 4.049 & 3 & .256 \\
\hline $\mathrm{N}$ of Valid Cases & 850 & & \\
\hline $\begin{array}{l}\text { 2017: Residence and customer } \\
\text { satisfaction }\end{array}$ & Value & Df & $\begin{array}{c}\text { Asymptotic Significance } \\
\text { (2-sided) }\end{array}$ \\
\hline Pearson Chi-Square & $74.795^{\mathrm{a}}$ & 12 & .000 \\
\hline Likelihood Ratio & 79.502 & 12 & .000 \\
\hline $\mathrm{N}$ of Valid Cases & 850 & & \\
\hline $\begin{array}{l}\text { 2017: Level of education and } \\
\text { customer satisfaction }\end{array}$ & Value & Df & $\begin{array}{c}\text { Asymptotic Significance } \\
\text { (2-sided) }\end{array}$ \\
\hline Pearson Chi-Square & $24.088^{\mathrm{a}}$ & 6 & .001 \\
\hline Likelihood Ratio & 24.214 & 6 & .000 \\
\hline $\mathrm{N}$ of Valid Cases & 850 & & \\
\hline $\begin{array}{l}\text { 2017: Income and customer } \\
\text { satisfaction }\end{array}$ & Value & Df & $\begin{array}{c}\text { Asymptotic Significance } \\
\text { (2-sided) }\end{array}$ \\
\hline Pearson Chi-Square & $13.458^{\mathrm{a}}$ & 9 & .143 \\
\hline Likelihood Ratio & 12.673 & 9 & .178 \\
\hline $\mathrm{N}$ of Valid Cases & 850 & & \\
\hline
\end{tabular}


As we can infer from the first table on data from 2017, variables like: age, residence, education are significant whereas gender and income tend to show no significance.

H1 - As can be inferred, we are $95 \%$ confident that there is a significant relationship between age of customers and the level of satisfaction on online services.

Out of total respondents, 254 belong to the group of people up to 24 years. $3 \%$ of those seem not be satisfied with online services, followed by $30 \%$ who are less satisfied, $47 \%$ are averagely satisfied and the rest $20 \%$ are very satisfied. Respondents between the age of 25-34 amount for total of 367, where the majority (50\%) of them are averagely satisfied. On the other hand, 229 respondents are above the age of 35 years. $44 \%$ of them show average satisfaction, whereas none of them is not satisfied.

$\mathrm{H} 2$ - There is a no significant relationship between gender of customers and the level of satisfaction with online services $(r=0.264$, where $\alpha=0.05)$. Therefore, gender does not affect consumer satisfaction.

H3 - With $95 \%$ confidence, we can say that location does matter in the sense of explaining consumer satisfaction. Prishtina leads with the highest number of very satisfied customers followed by Gjakova, Prizeren, Peja and Mitrovica.

H4 - Additionally, the level of education seems to be significant as well. It is worth noting that $51 \%$ of the respondents have a university degree or above. Out of those, the majority (55\%) express average satisfaction.

H5 - With an $\alpha$ of 0.143 , we are $95 \%$ confident that different levels of income in 2017 has no effect on consumer satisfaction when it comes to online services in Kosovo.

Contrary in 2019, income has drifted from being insignificant in 2017 to being significant in 2019. The rest of the variables have remained in the same significance category.

Table 2: Chi-Square Tests, Contingency Test 2019

\begin{tabular}{|c|c|c|c|}
\hline 2019: Age and customer satisfaction & Value & Df & $\begin{array}{l}\text { Asymptotic Significance } \\
\text { (2-sided) }\end{array}$ \\
\hline Pearson Chi-Square & $22.467^{\mathrm{a}}$ & 6 & .001 \\
\hline Likelihood Ratio & 24.761 & 6 & .000 \\
\hline $\mathrm{N}$ of Valid Cases & 850 & & \\
\hline $\begin{array}{l}\text { 2019: Gender and customer } \\
\text { satisfaction }\end{array}$ & Value & Df & $\begin{array}{c}\text { Asymptotic Significance } \\
\text { (2-sided) }\end{array}$ \\
\hline Pearson Chi-Square & $3.242^{\mathrm{a}}$ & 3 & .356 \\
\hline Likelihood Ratio & 3.350 & 3 & .341 \\
\hline $\mathrm{N}$ of Valid Cases & 850 & & \\
\hline $\begin{array}{l}\text { 2019: Residence and customer } \\
\text { satisfaction }\end{array}$ & Value & Df & $\begin{array}{c}\text { Asymptotic Significance } \\
\text { (2-sided) }\end{array}$ \\
\hline Pearson Chi-Square & $132.068^{\mathrm{a}}$ & 12 & .000 \\
\hline Likelihood Ratio & 149.279 & 12 & .000 \\
\hline
\end{tabular}


Table 2. Continued

\begin{tabular}{|l|c|c|c|}
\hline 2019: Age and customer satisfaction & Value & Df & $\begin{array}{c}\text { Asymptotic Significance } \\
\text { (2-sided) }\end{array}$ \\
\hline N of Valid Cases & 850 & & Df \\
\hline $\begin{array}{l}\text { 2019: Level of education and } \\
\text { customer satisfaction }\end{array}$ & Value & 6 & $\begin{array}{c}\text { Asymptotic Significance } \\
\text { (2-sided) }\end{array}$ \\
\hline Pearson Chi-Square & $21.072^{\mathrm{a}}$ & 6 & .002 \\
\hline Likelihood Ratio & 21.155 & & .002 \\
\hline N of Valid Cases & 850 & Df & $\begin{array}{c}\text { Asymptotic Significance } \\
\text { (2-sided) }\end{array}$ \\
\hline $\begin{array}{l}\text { 2019: Income and customer } \\
\text { satisfaction }\end{array}$ & Value & 9 & .000 \\
\hline Pearson Chi-Square & $32.794^{\mathrm{a}}$ & 9 & .000 \\
\hline Likelihood Ratio & 37.004 & & \\
\hline N of Valid Cases & 850 & & \\
\hline
\end{tabular}

\section{Consumer satisfaction, marketing mix: $4 P$}

Marketing Mix is defined as a set of tactical and controlled marketing instruments that the enterprise combines in order to meet the needs and satisfaction of its customers (Kotler, \& Keller, 2012). Marketing Mix consists of everything the enterprise can do to influence growth for its products and services. Numerous opportunities can be grouped into four variables or instruments known as "4 P's":

- Product

- Price

- Place (Distributions)

- Promotions

Therefore, the following hypotheses are:

H6 - Product variation has a positive effect on customer satisfaction.

H7 - Satisfaction with prices has a positive effect on customer satisfaction.

H8 - Satisfaction with promotion has a positive effect on customer satisfaction.

H9 - Satisfaction with distribution has a positive effect on customer satisfaction.

In addition, two other important variables have been added to the equation, and thus, H10 - Satisfaction with delivery time has a positive effect on customer satisfaction.

H 11 - Satisfaction with customer care has a positive effect on customer satisfaction.

\section{Reliability of variables - Cronbach's Alpha}

The table below shows Cronbach's Alpha or the scale of reliability of variables. As can be observed, all of the selected variables have been proven to be reliable and 
therefore a good representation of consumer satisfaction. In 2017, product variation was the most reliable variable with the highest $\alpha(\alpha=0.988)$. On the other hand, in 2019 , with and $\alpha$ of 0.996 , price has shown to be the most reliable variable.

Table 3: Cronbach's Alpha

\begin{tabular}{|c|c|c|}
\hline Model & $\begin{array}{c}\text { Cronbach's Alpha } \\
2017 \\
\end{array}$ & $\begin{array}{c}\text { Cronbach's Alpha } \\
2019 \\
\end{array}$ \\
\hline Product & .988 & .915 \\
\hline Price & .975 & .996 \\
\hline Promotion & .925 & .894 \\
\hline Distribution & .966 & .971 \\
\hline Delivery time & .963 & .976 \\
\hline Customer care & .969 & .990 \\
\hline
\end{tabular}

a. Dependent Variable: Satisfaction with online services

\section{Bivariate correlation}

In the following correlation table, we will see a value for the Pearson $r$ coefficient, Significance level Sig. (2-tailed) and a number (N) of the cases that are used in the correlation. Since we used the Pearson coefficient of correlation, we will have it in each column of the table.

Table 4: Analysis of correlation between variables 2017

\begin{tabular}{|l|l|c|c|c|c|c|c|c|}
\hline \multicolumn{2}{|l|}{} & $\begin{array}{c}\text { Variety of } \\
\text { products }\end{array}$ & Prices & Promotion & Distribution & Shipping & $\begin{array}{c}\text { Customer } \\
\text { care }\end{array}$ & $\begin{array}{c}\text { Online } \\
\text { services }\end{array}$ \\
\hline $\begin{array}{l}\text { Variety of } \\
\text { products }\end{array}$ & $\begin{array}{l}\text { Pearson } \\
\text { Correlation }\end{array}$ & 1 & $.964^{* *}$ & $.857^{* *}$ & $.929^{* *}$ & $.920^{* *}$ & $.936^{* *}$ & $.977^{* *}$ \\
\cline { 2 - 9 } & Sig. (2-tailed) & & .000 & .000 & .000 & .000 & .000 & .000 \\
\cline { 2 - 9 } & $\mathrm{N}$ & 850 & 850 & 850 & 850 & 850 & 850 & 850 \\
\hline \multirow{3}{*}{ Prices } & $\begin{array}{l}\text { Pearson } \\
\text { Correlation }\end{array}$ & $.964^{* *}$ & 1 & $.848^{* *}$ & $.917^{* *}$ & $.904^{* *}$ & $.922^{* *}$ & $.951^{* *}$ \\
\cline { 2 - 9 } & Sig. (2-tailed) & .000 & & .000 & .000 & .000 & .000 & .000 \\
\cline { 2 - 10 } & $\mathrm{N}$ & 850 & 850 & 850 & 850 & 850 & 850 & 850 \\
\hline \multirow{3}{*}{ Promotion } & $\begin{array}{l}\text { Pearson } \\
\text { Correlation }\end{array}$ & $.857^{* *}$ & $.848^{* *}$ & 1 & $.837^{* *}$ & $.821^{* *}$ & $.846^{* *}$ & $.861^{* *}$ \\
\cline { 2 - 9 } & Sig. (2-tailed) & .000 & .000 & & .000 & .000 & .000 & .000 \\
\cline { 2 - 9 } & $\mathrm{N}$ & 850 & 850 & 850 & 850 & 850 & 850 & 850 \\
\hline Distribution & $\begin{array}{l}\text { Pearson } \\
\text { Correlation }\end{array}$ & $.929^{* *}$ & $.917^{* *}$ & $.837^{* *}$ & 1 & $.893^{* *}$ & $.907^{* *}$ & $.935^{* *}$ \\
\cline { 2 - 9 } & Sig. (2-tailed) & .000 & .000 & .000 & .000 & & 1 & .000 \\
\cline { 2 - 9 } & $\mathrm{N}$ & 850 & 850 & 850 & 850 & 850 & 850 & 850 \\
\hline
\end{tabular}


Table 4. Continued

\begin{tabular}{|c|c|c|c|c|c|c|c|c|}
\hline & & $\begin{array}{c}\text { Variety of } \\
\text { products }\end{array}$ & Prices & Promotion & Distribution & Shipping & $\begin{array}{c}\text { Customer } \\
\text { care }\end{array}$ & $\begin{array}{c}\text { Online } \\
\text { services }\end{array}$ \\
\hline \multirow[t]{3}{*}{ Shipping } & $\begin{array}{l}\text { Pearson } \\
\text { Correlation }\end{array}$ & $.920^{* * *}$ & $.904^{* *}$ & $.821^{* *}$ & $.893^{* *}$ & 1 & $.905^{* *}$ & $.930^{* *}$ \\
\hline & \begin{tabular}{|l|} 
Sig. (2-tailed) \\
\end{tabular} & .000 & .000 & .000 & .000 & & 1 & .000 \\
\hline & $\mathrm{N}$ & 850 & 850 & 850 & 850 & 850 & 850 & 850 \\
\hline \multirow[t]{3}{*}{$\begin{array}{l}\text { Customer } \\
\text { care }\end{array}$} & \begin{tabular}{|l|} 
Pearson \\
Correlation \\
\end{tabular} & $.936^{* *}$ & $.922^{* *}$ & $846{ }^{* *}$ & $.907^{* *}$ & $.905^{* *}$ & 1 & $.940^{* *}$ \\
\hline & \begin{tabular}{|l|} 
Sig. (2-tailed) \\
\end{tabular} & .000 & & .000 & .000 & .000 & & .000 \\
\hline & $\mathrm{N}$ & 850 & 850 & 850 & 850 & 850 & 850 & .850 \\
\hline \multirow[t]{3}{*}{$\begin{array}{l}\text { Online } \\
\text { services }\end{array}$} & \begin{tabular}{|l|} 
Pearson \\
Correlation \\
\end{tabular} & $.977^{* *}$ & $.951^{* *}$ & $.861^{* *}$ & $.935^{* *}$ & $.930^{* *}$ & $.940^{* *}$ & 1 \\
\hline & \begin{tabular}{|l|} 
Sig. (2-tailed) \\
\end{tabular} & .000 & .000 & .000 & .000 & .000 & .000 & \\
\hline & $\mathrm{N}$ & 850 & 850 & 850 & 850 & 850 & 850 & 850 \\
\hline
\end{tabular}

The correlation coefficient shows that there was correlation between all variables and consumer satisfaction on online services in Kosovo in 2017. In that context, the correlation coefficient for product variation is $\mathrm{r}=.977$; price is $\mathrm{r}=.951$; promotion $r=.861$; distribution $r=.935$; delivery time $r=.930$; and costumer care with an $r$ of .940 . Therefore, there is a strong link between the variables.

Table 5: Analysis of correlation between variables 2019

\begin{tabular}{|c|c|c|c|c|c|c|c|c|}
\hline & & $\begin{array}{l}\text { Variety of } \\
\text { products }\end{array}$ & Price & Promotion & Distribution & Shipping & $\begin{array}{c}\text { Customer } \\
\text { care }\end{array}$ & $\begin{array}{c}\text { Online } \\
\text { services }\end{array}$ \\
\hline \multirow[t]{3}{*}{$\begin{array}{l}\text { Variety of } \\
\text { products }\end{array}$} & $\begin{array}{l}\text { Pearson } \\
\text { Correlation }\end{array}$ & 1 & $.838^{* *}$ & $.714^{* *}$ & $.793^{* *}$ & $.799^{* *}$ & $.822^{* *}$ & $.844^{* *}$ \\
\hline & Sig. (2-tailed) & & .000 & .000 & .000 & .000 & .000 & .000 \\
\hline & $\mathrm{N}$ & 850 & 850 & 850 & 850 & 850 & 850 & 850 \\
\hline \multirow[t]{3}{*}{ Prices } & \begin{tabular}{|l|} 
Pearson \\
Correlation
\end{tabular} & $.838^{* *}$ & 1 & $.816^{* *}$ & $.937^{* *}$ & $.946^{* *}$ & $.971^{* *}$ & $.922^{* *}$ \\
\hline & Sig. (2-tailed) & .000 & & .000 & .000 & .000 & .000 & .000 \\
\hline & $\mathrm{N}$ & 850 & 850 & 850 & 850 & 850 & 850 & 850 \\
\hline \multirow[t]{3}{*}{ Promotion } & $\begin{array}{l}\text { Pearson } \\
\text { Correlation }\end{array}$ & $.714^{* *}$ & $.816^{* *}$ & 1 & $.785^{* *}$ & $.778^{* *}$ & $.783^{* *}$ & $.815^{* *}$ \\
\hline & Sig. (2-tailed) & .000 & .000 & & .000 & .000 & .000 & .000 \\
\hline & $\mathrm{N}$ & 850 & 850 & 850 & 850 & 850 & 850 & 850 \\
\hline \multirow[t]{3}{*}{ Distribution } & \begin{tabular}{|l|} 
Pearson \\
Correlation
\end{tabular} & $.793^{* *}$ & $.937^{* *}$ & $.785^{* *}$ & 1 & $.920^{* *}$ & $.922^{* *}$ & $.944^{* *}$ \\
\hline & Sig. (2-tailed) & .000 & .000 & .000 & & .000 & .000 & .000 \\
\hline & $\mathrm{N}$ & 850 & 850 & 850 & 850 & 850 & 850 & 850 \\
\hline
\end{tabular}


Table 5. Continued

\begin{tabular}{|l|l|c|c|c|c|c|c|c|}
\hline \multicolumn{2}{|l}{} & $\begin{array}{c}\text { Variety of } \\
\text { products }\end{array}$ & Price & Promotion & Distribution & Shipping & $\begin{array}{c}\text { Customer } \\
\text { care }\end{array}$ & $\begin{array}{c}\text { Online } \\
\text { services }\end{array}$ \\
\hline $\begin{array}{l}\text { Delivery } \\
\text { time }\end{array}$ & $\begin{array}{l}\text { Pearson } \\
\text { Correlation }\end{array}$ & $.799^{* *}$ & $.946^{* *}$ & $.778^{* *}$ & $.920^{* *}$ & 1 & $.933^{* * *}$ & $.954^{* *}$ \\
\cline { 2 - 9 } & Sig. (2-tailed) & .000 & .000 & .000 & .000 & & .000 & .000 \\
\cline { 2 - 9 } & $\mathrm{N}$ & 850 & 850 & 850 & 850 & 850 & 850 & 850 \\
\hline $\begin{array}{l}\text { Customer } \\
\text { care }\end{array}$ & $\begin{array}{l}\text { Pearson } \\
\text { Correlation }\end{array}$ & $.822^{* * *}$ & $.971^{* * *}$ & $783^{* *}$ & $.922^{* * *}$ & $.933^{* *}$ & 1 & $.980^{* *}$ \\
\hline & Sig. (2-tailed) & .000 & & .000 & .000 & .000 & & .000 \\
\hline & $\mathrm{N}$ & 850 & 850 & 850 & 850 & 850 & 850 & .850 \\
\hline $\begin{array}{l}\text { Online } \\
\text { services }\end{array}$ & $\begin{array}{l}\text { Pearson } \\
\text { Correlation }\end{array}$ & $.844^{* *}$ & $.992^{* *}$ & $.815^{* *}$ & $.944^{* *}$ & $.954^{* *}$ & $.980^{* * *}$ & 1 \\
\hline & Sig. (2-tailed) & .000 & .000 & .000 & .000 & .000 & .000 & \\
\hline & $\mathrm{N}$ & 850 & 850 & 850 & 850 & 850 & 850 & 850 \\
\hline
\end{tabular}

**. Correlation is significant at the 0.01 level (2-tailed).

Accordingly, data from 2019 show that there is still correlation between all variables, where the price of products has the highest correlation coefficient with consumer satisfaction $(\mathrm{r}=.992)$. Additionally, promotion has a similar coefficient of correlation in 2019 of $\mathrm{r}=.815$; distribution $\mathrm{r}=.944$; delivery time $\mathrm{r}=.954$ and customer care $r=.980$. On the other hand, product variation has dropped as a coefficient of correlation from $\mathrm{r}=.977$ to $\mathrm{r}=.844$.

\section{Multivariate regression}

Regression analysis method is a method used to find the relation between the dependent variable $\mathrm{Y}$ and independent variables $\mathrm{X} 1, \mathrm{X} 2, \mathrm{X} 3, \ldots$.

Table 6: Multivariate regression 2017

\begin{tabular}{|c|c|c|c|c|}
\hline Model Summary & R & R Square & Adjusted R Square & $\begin{array}{c}\text { Std. Error of the } \\
\text { Estimate }\end{array}$ \\
\hline Model & $.983^{\mathrm{a}}$ & .966 & .966 & .137 \\
\hline
\end{tabular}

a. Predictors: (Constant), Satisfaction with distribution, Satisfaction with the promotion, Satisfaction with prices, Satisfaction with the variety of products, delivery time, customer care.

b. Dependent Variable: Consumer Satisfaction

Value $\mathrm{R}$ represents the coefficient of correlation between independent variables with the dependent variable. In this case, $r=.983$ indicates that independent variables and the dependent variable have a strong positive correlation. From this we are able to conclude that the value of $\mathrm{R}$ indicates a satisfactory level of prediction of the depen- 
dent variable $\mathrm{Y}$ - customer satisfaction. The value for $\mathrm{R}$ Squared is 0.966 and reflects the coefficient of determination which is used to identify how independent variables are able to predict the dependent variable. Adjusted R Squared equals 0.966 and is the adjustment of the value of R Squared. As seen, R Squared and adjusted R Squared do not differ (.966), so we are certain that independent variables indicate $95 \%$ variation in the dependent variable.

Table 7: Analysis of multivariate regression 2019

\begin{tabular}{|c|c|c|c|c|}
\hline Model Summary & R & R Square & Adjusted R Square & $\begin{array}{c}\text { Std. Error of the } \\
\text { Estimate }\end{array}$ \\
\hline 1 & $.996^{\mathrm{a}}$ & .991 & .991 & .071 \\
\hline
\end{tabular}

Value $\mathrm{R}$ represents the coefficient of correlation between independent variables with the dependent variable. In 2019, $\mathrm{r}=.996$ indicates that independent variables and the dependent variable have a strong positive correlation. From this we are able to conclude that the value of $\mathrm{R}$ indicates a satisfactory level of prediction of the dependent variable $\mathrm{Y}$ - customer satisfaction. The value for $\mathrm{R}$ Squared is 0.991 and reflects the coefficient of determination which is used to identify how independent variables are able to predict the dependent variable. Adjusted R Squared equals 0.991 and is the adjustment of the value of R Squared. As seen, R Squared and adjusted R Squared do not differ (.991), so we are certain that independent variables indicate $95 \%$ variation in the dependent variable.

Table 8: Analysis of variance 2017

\begin{tabular}{|c|c|c|c|c|c|c|}
\hline \multicolumn{2}{|c|}{ ANOVA $^{\mathbf{a}}$} & \multicolumn{1}{l|}{} & Sig. \\
\hline \multirow{2}{*}{1} & Model & Sum of Squares & df & Mean Square & F & $.000^{\text {b }}$ \\
\cline { 2 - 8 } & Regression & 446.934 & 6 & 74.489 & 3976.771 & \\
\cline { 2 - 8 } & Residual & 15.790 & 843 & .019 & & \\
\hline
\end{tabular}

a. Dependent Variable: Satisfaction with online services

b. Predictors: (Constant), Satisfaction with distribution, Satisfaction with the promotion, Satisfaction with prices, Satisfaction with the variety of products, Shipping, customer care.

From the analysis of variance (ANOVA) from the data taken in 2017, presented in the table above, we can see that the model is significant at $\alpha=0.000$. ANOVA results indicate that in general the independent variables have a significant correlation with the dependent variable, respectively with overall customer satisfaction which has taken the values $\mathrm{F}=3976.771$ and $\mathrm{p}=0.000$. 
Table 9: Analysis of the variance 2019

\begin{tabular}{|c|c|c|c|c|c|c|}
\hline \multicolumn{7}{|c|}{ ANOVA $^{a}$} \\
\hline \multicolumn{2}{|r|}{ Model } & Sum of Squares & Df & Mean Square & $\mathrm{F}$ & Sig. \\
\hline \multirow{3}{*}{1} & Regression & 481.930 & 6 & 80.322 & 15972.310 & $.000^{\mathrm{b}}$ \\
\hline & Residual & 6.239 & 843 & .005 & & \\
\hline & Total & 486.169 & 849 & & & \\
\hline
\end{tabular}

From analysis of variance (ANOVA) from the data in 2019, presented in the table above, we can see that the model is significant at $\alpha=0.000$. ANOVA results indicate that in general the independent variables have a significant correlation with the dependent variable, respectively with overall customer satisfaction which has taken the values $\mathrm{F}=15972.310$ and $\mathrm{p}=0.000$.

Table 10: Regression coefficients and significance between the independent variables 2017

\begin{tabular}{|c|c|c|c|c|c|}
\hline \multirow{2}{*}{ Model } & \multicolumn{6}{|c|}{ Coefficients $^{\mathbf{a}}$} & \multicolumn{2}{c|}{ Sig. } \\
\cline { 2 - 5 } & Unstandardized Coefficients & $\begin{array}{c}\text { Standardized } \\
\text { Coefficients }\end{array}$ & t & \\
\hline (Constant) & -.103 & .020 & & -5.106 & .000 \\
\hline Variety of products & .610 & .030 & .597 & 20.580 & .000 \\
\hline Satisfaction with prices & .015 & .026 & .015 & .581 & .591 \\
\hline $\begin{array}{c}\text { Satisfaction with the } \\
\text { promotion }\end{array}$ & .034 & .013 & .034 & 2.623 & .009 \\
\hline $\begin{array}{c}\text { Satisfaction with } \\
\text { distribution }\end{array}$ & .119 & .019 & .115 & 6.150 & .000 \\
\hline Delivery time & .137 & .018 & .132 & 7.561 & .000 \\
\hline Customer care & .118 & .020 & .115 & 5.787 & .000 \\
\hline
\end{tabular}

a. Dependent Variable: Satisfaction with online services

According to the table above we can conclude that:

H6 - "Variety of products has a positive effect on customer satisfaction" is approved, because the significance value is smaller than 0.05 where the value of significance in this case is $\mathrm{p}=0.000$.

$\mathrm{H} 7$ - "Satisfaction with prices has a positive effect on customer satisfaction" is not approved, because the significance value is bigger than 0.05 where the value of significance in this case is $\mathrm{p}=0.591$.

H8 - "Satisfaction with promotion has a positive effect on customer satisfaction" is approved, because the significance value is smaller than 0.05 where the value of significance in this case is $\mathrm{p}=0.009$.

H9 - "Satisfaction with distribution has a positive effect on customer satisfaction" is approved, because the significance value is smaller than 0.05 where the value of significance in this case is $p=0.000$. 
H10 - "Satisfaction with shipping has a positive effect on customer satisfaction" is approved, because the significance value is smaller than 0.05 where the value of significance in this case is $\mathrm{p}=0.000$.

H11 - "Satisfaction with customer care has a positive effect on customer satisfaction" is approved, because the significance value is smaller than 0.05 where the value of significance in this case is $\mathrm{p}=0.000$.

Table 11: Regression coefficients and significance between the independent variables 2019

\begin{tabular}{|c|c|c|c|c|c|}
\hline \multicolumn{6}{|c|}{ Coefficients $^{\mathrm{a}}$} \\
\hline \multirow[t]{2}{*}{ Model } & \multicolumn{2}{|c|}{ Unstandardized Coefficients } & $\begin{array}{c}\text { Standardized } \\
\text { Coefficients }\end{array}$ & \multirow[t]{2}{*}{$\mathrm{t}$} & \multirow[t]{2}{*}{ Sig. } \\
\hline & $\mathrm{B}$ & Std. Error & Beta & & \\
\hline (Constant) & -.029 & .010 & & -2.823 & .005 \\
\hline Variety of products & .027 & .006 & .028 & 4.672 & .000 \\
\hline $\begin{array}{l}\text { Satisfaction with } \\
\text { prices }\end{array}$ & .555 & .017 & .563 & 33.180 & .000 \\
\hline $\begin{array}{l}\text { Satisfaction with the } \\
\text { promotion }\end{array}$ & .013 & .005 & .014 & 2.561 & .011 \\
\hline $\begin{array}{l}\text { Satisfaction with } \\
\text { distribution }\end{array}$ & .064 & .010 & .062 & 6.400 & .000 \\
\hline Delivery time & .085 & .011 & .084 & 8.027 & .000 \\
\hline Customer care & .268 & .014 & .263 & 19.131 & .000 \\
\hline
\end{tabular}

a. Dependent Variable: Satisfaction with online services

According to the table above we can conclude that:

H6 - "Variety of products has a positive effect on customer satisfaction" is approved, because the significance value is smaller than 0.05 where the value of significance in this case is $\mathrm{p}=0.000$.

H7 - "Satisfaction with prices has a positive effect on customer satisfaction" is approved, because the significance value is smaller than 0.05 where the value of significance in this case is $\mathrm{p}=0.000$.

H8 - "Satisfaction with promotion has a positive effect on customer satisfaction" is approved, because the significance value is smaller than 0.05 where the value of significance in this case is $\mathrm{p}=0.011$.

H9 - "Satisfaction with distribution has a positive effect on customer satisfaction" is approved, because the significance value is smaller than 0.05 where the value of significance in this case is $\mathrm{p}=0.000$.

H10 - "Satisfaction with shipping has a positive effect on customer satisfaction" is approved, because the significance value is smaller than 0.05 where the value of significance in this case is $\mathrm{p}=0.000$.

H11 - "Satisfaction with customer care has a positive effect on customer satisfaction" is approved, because the significance value is smaller than 0.05 where the value of significance in this case is $\mathrm{p}=0.000$. 


\section{Conclusions}

The positioning of companies that operate in Kosovo market through online platforms shall continue to develop as the companies are in the initial stage and it is a concern if they wait for the development to take place as a process on its own. Moves ahead shall be made with the strategy of differentiation based on quality in order for them to provide superior products.

The strategy of innovation in the market that the online companies have used is a suitable strategy that provides variety and is financially beneficial. They shall use the advantages that it provides.

From marketing research, we have found that most of the respondents have high level of education and their frequency in using online platforms is very important, 435 of the respondents in 2017 had high education which remained almost the same with 437. Another important element is competition. Following the analysis that were made, it was found that apart from local competition, customers prefer to make online purchases even from other platforms abroad in order to meet their needs and desires.

The experience associated with purchases made from in store still remains irreplaceable to a good number of people. Nevertheless, the dynamics of life and the ever-decreasing free time is orienting customers towards making purchases from the comfort of their homes. Furthermore, it is continuously getting easier and more comfortable initiate purchases from e-commerce, which is yet another reason for companies to turn their heads towards online platforms.

The lack of products offered locally, has oriented customers towards international web sites, in the search for their desired products. Therefore, a number of consumers have been aware of online platforms thus, we assume that adapting to this new way of buying and selling goods and services may be fairly easy. Firms may benefit from this and ensure sustainable competitive advantage if they manage to implement this technology in accordance with rapid changes in technology.

From personal experience and online sales practices, the customers are aware of the performances, capacity, camera, processor, operational system etc. of a smart phone, and one can find this out in the beginning of a conversation with a customer. Therefore, a demanding customer always expects developments to take place in line with global developments.

The general discussions about high prices in Kosovo may be the main factor of dissatisfaction among consumers. From the data of the research not many consumers are satisfied with the prices offered by online platforms in Kosovo.

Firms may want to invest in decreasing the time it takes them to initiate a sale up to the time it takes them to deliver a product or service. As the analysis has shown, consumers value their time therefore expect timely delivery, with additional satisfaction if their expectation is surpassed. 
Post purchase phone calls, daily/weekly discounts, gifts for regular buyers, emails with information on new products are only some of the forms that can be used to earn the trust of the customers. A satisfied customer with the item he or she purchases will not forget to purchase same types or similar types of products or services in the future because he or she has experienced satisfaction, belief and trust on the items purchased previously.

Equally important would be to invest in special training of employees in regard to the new era of online platforms in the sense that employees need to understand the message that their company wishes to deliver, for them to be able to deliver to their customers.

Kosovo remains in the early stages of online platform development as well as e-commerce. As such, the current situation does represent a unique opportunity for firms to exploit the benefits of e-commerce, in order to boost sales as well as reduce fixed and variable cost - leading to the creation of competitive advantage. Furthermore, an e-commerce focused firm may find it easier to follow the concept of the triple bottom line where focusing for people and the environment proves to be equally important as focusing in the financial part of the business.

\section{REFERENCES}

Barney, J. (1991). Firm Resources and Sustained Competitive Advantage. Texas A\&M University. Journal of Management,17(1), 99-120. doi:10.1177/014920639101700108

Garren, S. T. (1998). Maximum likelihood estimation of the correlation coefficient in a bivariate normal model with missing data. Statistics \& Probability Letters,38(3), 281-288. doi:10.1016/ s0167-7152(98)00035-2

Grandon, E. E., \& Pearson, J. (2004). Electronic commerce adoption: An empirical study of small and medium US businesses. Information \& Management,42(1), 197-216. doi:10.1016/j. im.2003.12.010

Kotler, P., \& Keller, K. L. (2012). Marketing management. New Jersey: Prentice Hall

Pearson, K. (1904). On the theory of contingency and its relation to association and normal correlation. London: Cambridge University Press.

Porter, M. E. (1980). Competitive strategy techniques for analyzing industries and competitors. New York: Free Pr.

Rifkin, J. (2013). The third industrial revolution: How lateral power is transforming energy, the economy, and the world. Basingstoke: Palgrave Macmillan.

Shafiee, M. M., \& Bazargan, N. A. (2018). Behavioral Customer Loyalty in Online Shopping: The Role of E-Service Quality and E-Recovery. Journal of Theoretical and Applied Electronic Commerce Research,13(1), 26-38. doi:10.4067/s0718-18762018000100103

Wilson, A., Zeithaml, V. A., Bitner, M. J., \& Gremler, D. D. (2016). Services marketing: Integrating customer focus across the firm. Maidenhead, Berkshire: McGraw-Hill Education. 